Jurnal At-Tibyan: Jurnal Ilmu Alqur'an dan Tafsir Volume 6 No. 2, Desember 2021 (p. 182-203)

P ISSN 2442-594X | E ISSN 2579-5708

http://journal.iainlangsa.ac.id/index.php/tibyan

\title{
THE NEW PARADIGM OF SURAH AL FATIHAH BASED ON THE KEY CONCEPTS OF SOCIAL INTERPRETATION OF DAWAM RAHARJO
}

\author{
Miftahul Janah \\ Institut Agama Islam Bakti Negara (IBN) Tegal, Indonesia \\ Miftahuljinan@gmail.com \\ Haerudin \\ University Of The Holy Quran and Taseel Of Science, Sudan \\ haerudin@ubpkarawang.ac.id \\ DOI 10.32505/at-tibyan.v6i2.1911

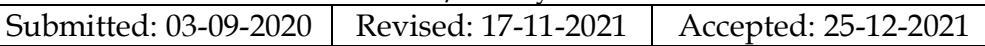

\begin{abstract}
:
When interpreting the Qur'an, a mufassir needs a paradigm and a foundation as the procedures and stages that become his reference. This paper attempts to discuss the paradigm and concept of interpretation promoted by Dawam Rahardjo, namely al-Fātihah as the Qur'an in a nutshell which is contained in the work of the Ensiklopedi Al-Quran: Tafsir Sosial Berdasarkan KonsepKonsep Kunci. Two objectives in this study, first, the arguments that make alFâtihah a paradigm and the extent to which these arguments can be justified. Second, steps, systematics and forms of interpretation by positioning alFātiḥah as a paradigm and its shortcomings in interpreting the Qur'an. This research is in the form of library research in the form of descriptive-analysis and uses content analysis as the analytical method used. This discussion concludes that there are two verses of the Qur'an, namely QS. Ali Imran (03): 07 and QS. al-Hijr (15): 87 as the basis and form three conceptual frameworks of al-Fātihah as a paradigm of interpretation of the Qur'an, namely the term ummu al-kitab as the attribution of surah al-Fātihah, the two ummu al-kitab referred to as muhkām and the last term al-sab'u al-masianni which is also understood as al-Fātihah. The weakness in the argument that is built is in the redefinition of muhkàm or mutasyabì which do not have clear standards and references. While the form of interpretation with this concept ends with a systematic form of thematic presentation with two steps or procedures, namely departing from the key terms in Surat al-Fātihah (inductive) and starting from other than Surat al-Fātiḥah then returning to Surat al-Fātihạh (deductive). The first procedure has difficulties in developing the -evolutionist dimension-, while the second procedure will be very subjective because of the difficulty of matching the interpreted verse with the terms in Surah alFātiḥah.
\end{abstract}

Keywords: Dawam Rahardjo, Al-Fätihhah, The Qur'an in a nutshell, Muhkāmmutasyābìh, Paradigm of interpretation

Copyright @ 2021. Owned by the Author, published by Jurnal At-Tibyan: Jurnal Ilmu Alqur'an dan Tafsir. Articles with open access. License: CC-BY 


\begin{abstract}
Abstrak:
Ketika menafsirkan al-Qur'an, seorang mufassir membutuhkan paradigma dan landasan sebagai prosedur dan tahapan yang menjadi rujukannya. Tulisan ini berupaya mendiskusikan paradigma dan konsep penafsiran yang diusung oleh Dawam Rahardjo, yakni al-Fātiḥah sebagai al-Qur'an in a nutshell yang tertuang dalam karya Ensiklopedi Al-Quran: Tafsir Sosial Berdasarkan Konsep-Konsep Kunci. Dua tujuan dalam kajian ini, pertama, argumentasi yang menjadikan al-Fātiḥah sebagai paradigma dan sejauhmana argumentasi tersebut dapat dipertanggung jawabkan. Kedua, langkah, sistematika dan bentuk penafsiran dengan memposisikan al-Fātiḥah sebagai paradigma dan kekurangannya dalam menafsirkan al-Qur'an. Penelitian ini berupa penelitian pustaka (library research) yang berupa deskriptif-analisis dan menggunakan analisis isi (content analysis) sebagai metode analisi yang digunakan. Diskusi ini menyimpulkan bahwa terdapat dua ayat al-Qur'an yakni QS. Ali Imran (03): 07 dan QS. al-Hijr (15): 87 sebagai landasan dan membentuk tiga kerangka konsep al-Fātiḥah sebagai paradigma penafsiran al-Qur'an, yaitu terma ummu al-kitab sebagai penisbatan surat al-Fātiḥah, kedua ummu alkitab yang disebut sebagai muhkam dan terakhir terma al-sab'u al-maśāni yang dipahami sebagai al-Fātihah pula. Kelemahan dalam argumentasi yang dibangun adalah pada redefinisi muhkam atau mutasyabih yang tidak memiliki standar dan rujukan yang jelas. Sementara wujud penafsiran dengan konsep ini berakhir dengan bentuk sistematika penyajian tematik dengan dua langkah atau prosedur, yakni berangkat dari istilah kunci pada surat al-Fātiḥah (induktif) dan bertolak dari selain surat al-Fātiḥah kemudian kembali surat alFātiḥah (deduktif). Prosedur pertama memiliki kesulitan dalam pengembangan -dimensi evolusionis-, sementara prosedur kedua akan sangat subjektif karena kesulitan mencocokan ayat yang ditasfirkan dengan istilah dalam surat alFātiḥah.
\end{abstract}

Kata kunci: Dawam Rahardjo, Al-Fätihah, Al-Qur'an in a nutshell, Muhkammutasyābih, Paradigma penafsiran.

\title{
Introduction
}

Changes and shifts are a necessity, not least in the area of interpretation paradigm. Changes in the interpretation paradigm will go hand in hand with changing times. This is because scientific constructs are products at a certain time that are not fully relevant and suitable for the future. In the present context and in the area of interpretation, various new paradigms have emerged in an effort to understand the Qur'an and to answer existing contemporary problems. ${ }^{1}$ Tafsir al-Maqasid, for example, makes maqasid sharia as the initial basis in the interpretation of the Qur'an so

\footnotetext{
${ }^{1}$ Wely Dozan, “Analysis Of Shifting Interpretation Paradigm: A Comparative Study Of Classic And Contemporary Era Tafsirs," At-Tibyan: Jurnal Ilmu Alqur'an Dan Tafsir 5, no. 1 (2020): 37-55, https://doi.org/10.32505/tibyan.
} 
that the maslahah ${ }^{2}$ or feminist interpretation is born from the basic principles of the Qur'an that are fair and equal in viewing men and women. ${ }^{3}$ The emergence and change of interpretive paradigms illustrates that the interpretation paradigm is an important area as a basis for renewal in the interpretation of the Qur'an.

In addition to the two paradigms above, there are many other paradigms of interpretation of the Qur'an that have developed, one of which and becomes an issue in this study is the paradigm of the Qur'an as a unit (al-Qur'an is unity). The existence of this paradigm is a critique of interpretations that are partial, atomistic and deny the unity of the verses of the Qur'an. However, in the concept of al-Qur'an is unity, several models appear, such as the Nizam al-Qur'an offered by al-Farahi which is based on the taufiqi composition of the Qur'an and I'jaz al-Qur'an, ${ }^{4}$ Wahdatu al-Qur'aniyah promoted by Sa'id Hawa started from the division of the letters of the Qur'an into four groups and munasabah, ${ }^{5}$ or al-Fātihah as the Qur'an in a Nutshell offered by Dawam Rahardjo in his work Ensiklopedi Al-Quran: Tafsir Sosial Berdasarkan Konsep-Konsep Kunci.

Al-Fātihah as al-Qur'an in a Nutshell positions it as a paradigm and of course has a basic foundation or construction on how the paradigm is built. Al-Fātihah is said to be the Ummu al-Qur'an which is the essence of the Qur'an. Many terms are used to refer to it which indicate that al-Fātihah has an important position. Therefore, in this context, al-Fātihah as the main basis for the interpretation of the Qur'an, especially in Indonesia, is generally carried out by mufassir. Call it the Tafsir Sufi al-Fātihah by Jalaluddin Rakhmat. ${ }^{6}$ Abdul Muin Salim's work entitled "Jalan Lurus Menuju Hati Sejahtera (Tafsir surat al-Fātihah)"77 or the work of Ahmad Chodjim with the title "Al-

\footnotetext{
${ }^{2}$ Syamsul Wathani, "Konfigurasi Nalar Tafsir Al-Maqāṣidī Pendekatan Sistem Interpretasi," Suhuf 9, no. 2 (2016): 293-319.

3 Eni Zulaiha, "Tafsir Feminis: Sejarah, Paradigma Dan Standar Validitas Tafsir Feminis," AlBayan: Jurnal Studi Ilmu Al- Qur'an Dan Tafsir 1, no. 1 (2016): 17-26, https://doi.org/10.15575/albayan.v1i1.1671.

${ }^{4}$ Miftahul Jannah, “Nizāam Al-Qur'ān,” MAGHZA: Jurnal Ilmu Al-Qur'an Dan Tafsir 3, no. 1 (2018): 79-92, https://doi.org/10.24090/maghza.v3i1.1957.

5 Mhd. Idris, "Karekteristik Kitab Al-Asas Fi Al-Tafsir Karya Sa'id Hawa," Ulunnuha 8, no. 1 (2019): 115-26.

${ }^{6}$ The work of Jalaluddin Rakhmat's commentary, basically, is more inclined to the muqaddimah of the Sufi interpretation of al-Fātihah. This is because in this work Jalaluddin Rakhmat did not interpret the verses of al-Fātihah. Existing discussions include; the names of the famous al-Fātihah, the virtues of al-Fātihah and ta'awwuz. What is interesting in this work is the existence of kasykul (small notes) in various forms and sourced from the Shia or Sunni scientific traditions. Rindom Harahap, "Tafsir Bil Ma’tsur Jalaluddin Rakhmat," El-Afkar 5, no. II (2016): 61.

7 The commentary of Abd. Muin Salim originally spoke Arabic under the name al-Nahj al-Qawim wa al-Shirath al-Mustaqim li al-Qalb al-Salim min Tafsir al-Qur'an al-'Azhim which was later translated with the title Jalan Lurus Menuju Hati Sejahtera (Tafsir al-Fātihah). The method of interpretation used is tahlili and interpretive procedures by writing verses, explanations of lafad or words, explaining the whole verse by outlining the wisdom and linking (munasabah) with other verses. Achmad, "Manhaj Abd. Muin Salim Dan Penerapannya Dalam Menafsirkan Surah Al-Fātiḥah,” Al-Daulah 1, no. 1 (2012): $16-32$.
} 
Fātiḥah Membuka Mata Batin dengan Surah Pembuka". ${ }^{8}$ The three works have a clear distinction with what Dawam has to offer, although they are both interested in studying and understanding Surat al-Fātiḥah. The three works positioned al-Fātiḥah as the object of interpretation or in terms of the science of interpretation called "classical thematic". ${ }^{9}$ Meanwhile, for Dawam, Al-Fātiḥah is placed as a paradigm or essence for understanding and interpreting the Qur'an. Therefore, it is interesting to study and discuss further.

Not many researchers have reviewed the concept of al-Fātiḥah as the Qur'an "in a Nutshell" that Dawam offers. Nevertheless, the work of the Ensiklopedi Al-Quran: Tafsir Sosial Berdasarkan Konsep-Konsep Kunci is an interpretation that departs from the key socio-religious terms contained in the Qur'an. This later became plus value of Dawam's interpretation, as praised by Nasaruddin Umar, because its sensitivity contained interpretations that had a dialect with reality, namely interpretations with Indonesian nuances. ${ }^{10}$ Islah Gusmian criticized Dawam's work, because his interpretation was indifferent to the socio-political events of the new order. In fact, the interpretation explains several things related to socio-political. ${ }^{11}$ Fadhli Lukman tries to read Dawam's thoughts on the Qur'an, interpretation, ta'wil and reason, because as an encyclopedia interpretation, these four terms are not mentioned in the 27 entries. $^{12}$ The reading of the interpretation of Dawam's work, as above, is still included in the content area of the interpretation, but has not reached yet in depth about the concept or paradigm of the interpretation of the Qur'an which is the basis of the interpretation of the Qur'an itself.

Departing from the above, this work aims to study and further examine the interpretation paradigm of Dawam Rahardjo. How are the arguments drawn up in building the concept of al-Fātihah as the Qur'an "in a Nutshell" or the paradigm of interpretation of the Qur'an? and to what extent can this concept be applied in the interpretation of the Qur'an? In line with the problem to be studied, this research has an important value as a form of developing an interpretive method. This research is library research so that it will describe and analyze the themes studied, while the analysis model used is content analysis. ${ }^{13}$

\footnotetext{
${ }^{8}$ Similar to Dawam, Ahmad Chodjim is not someone who is an expert in the field of interpretation, but has a work on the interpretation of al-Fātihah. This interpretation uses the tahlili method. The writing of the verse in this commentary uses Latin, not Arabic, then he translates it. After that explain the verse with a hadith or another verse. Ahmad Chodjim, Alfatihah: Membuka Mata Batin Dengan Surat Pembuka (Jakarta: Serambi, 2008): 7.

${ }^{9}$ Gusmian, Khazanah Tafsir Indonesia: Dari Hermeneutika Hingga Ideologi, 122.

${ }^{10}$ Nasarudin Umar, "Refleksi Sosial Dalam Memahami Al-Qur'an: Menimbang Ensiklopedi AlQur'an Karya M. Dawam Raharjdo,” Jurnal Studi Al-Qur'an 1, no. 3 (2006): 54.

${ }^{11}$ Gusmian, Khazanah Tafsir Indonesia Dari Hermeneutika Hingga Ideologi. 327

12 Fadhli Luqman, "Konsep Kunci Tafsir Alquran Ala Dawam Rahardjo," Jurnal Ilmu Alquran \& Hadis 4, No. 1 (2014). 62

${ }^{13}$ Imam Subrayogo, Metodologi Penelitian Sosial-Agama (Bandung: Remaja Rosda Karya, 2001). 71.
} 


\section{Biography of Dawam Rajardjo}

His full name is Muhammad Dawam Raharjdo, he was born on April 20, 1942 in the village of Baluwarti, Surakarta. His parents' name are M. Zuhdi Rahardjo and Mutmainah who were a respected and religious family. His father came from Tempur Sari Klaten, an area that became the forerunner of the Jamsaren Solo Islamic boarding school founded by KH. Zamahsari. From that, Dawam began to study religious education from the family environment. Starting from the guidance of his aunt, he learned to recite the Koran and was able to memorize several surah Juz 'Amma. When he was in Kindergarten he studied at Bustanul Atfal Muhammadiyah in Kauman. ${ }^{14}$

Dawam's formal education began in 1948 at the 46 Solo State Elementary School and in 1954 he graduated. Then he continued his education at MAN 1 Solo from 1954 to 1957. In Islamic scholarship, Dawam only studied at Madrasah Ibtidaiyah al-Islam in the afternoon from 1950 to 1956. From that madrasa, Dawam knew Islamic scholarship such as Arabic, Tafsir, Hadith, Fiqh. In addition, he once recited the Quran at KH. Ali Darokah, one of the scholars and general chairman of the Surakarta Ulema Council at that time. Dawam also studied Krapyak, the Al-Munawwir Islamic boarding school in Yogyakarta, to recite the Koran. After graduating from Dawam High School, he had the opportunity to study at the high school level in Boisie, Idaho, United States of America. through the screening of the American Field Services (AFC) program in 1960 to 1996 . Therefore, he did not immediately receive a college education. ${ }^{15}$

During a year in the United States, to complete his studies in Idaho, Dawam then continued his education at the Faculty of Economics at Gadjah Mada University, Yogyakarta in 1962 and completed in 1969. Meanwhile, M. Dawam Rahardjo's career has been quite long, starting when he was a staff member at the Bank of America Department, Jakarta (1969-1971). Worked at a research institute in the field of industry, namely FNS (Fricderich Naumann Stiftung). He was active in an NGO, namely LP3ES (Institute for Research and Economic-Social Development) in 19711978. In the academic field, he was the Director of Postgraduate Program at Muhammadiyah University of Malang. Listed as a Professor of Economics at the same campus (since 1993). He has served as Chancellor of 45 Bekasi Islamic University (UNISMA) since 1996-2001. Became a lecturer at the Institute for Management Education and Development (LPPM), Jakarta. In addition, he was also the editor-inchief of "Ulumul Qur'an", chairman of the Board of Directors of the Institute for Religious and Philosophical Studies (LSAF). At the same time, there were other positions held by Dawam such as becoming director of the International Institute of Islamic Thought (iii-T) in 1999 or President of The Board of Directors of the International Forum of Islamic Studies (IFIS) and others. ${ }^{16}$

\footnotetext{
${ }^{14}$ Umar, “Refleksi Sosial Dalam Memahami Al-Qur'an: Menimbang Ensiklopedi Al-Qur'an Karya M. Dawam Raharjdo.”, 49.

${ }^{15}$ Dawam Raharjdo, Islam Dan Transformasi Sosial-Ekonomi (Jakarta: LASF, 1999), x.

${ }^{16}$ Raharjdo, xi.
} 
The emergence of Dawam Rahardjo's interest, who is an expert in the socioeconomic sector, to study the Qur'an, as he himself admits, it comes from heart calling. This realization emerged in 1980 when he served as director of LP3ES (Institute for Economic and Social Research, Education and Research) and at that time he was 40 years old. From this, Dawam learned a lot and understood various commentaries and books related to the Quran. ${ }^{17}$ Some books that made an impression and influenced his thinking, among others; Tafsir Al-Azhar by Buya Hamka, The Holy Quran by Maulana Muhammad Ali, Major Themes of the Quran by Fazlur Rahman, Tafsir by Abu al-A'la al-Maududi. Not quite there, he also admired orientalist works such as Modern Moslem Koran Interpretation J.M.S Baljon, The Quran and it's Exegetes Germany Gort Helmut. $^{18}$

There are at least three factors that influence in constructing Dawam's Islamic understanding. First, the socio-religious and political situation in Indonesia at that time. The Indonesian Moeslem community at that time was still struggling with the discourse and understanding of the ideological and political antagonisms between Islam and the State. This will give a negative impact on Indonesian Moeslems. Second, Dawam's direct participation and activeness in the Yogyakarta HMI organization. HMI is one of the largest Islamic student organizations, so, the activities and agenda will be in direct contact with religious, social, political and economic discourses and developments. Third, Dawam joined the "Limited Group" discussion group which was directly mentored by Mukti Ali. Several young thinkers at that time, such as Djohan Effendi, Ahmad Wahib, Simuh, and Dawam himself became members. ${ }^{19}$

Dawam can be called a prolific writer, many of his works have been published, including; Pesantren dan Pembaharuan (Jakarta: LP3ES, 1974). Insan Kamil (Jakarta: Grafiti Press, 1985). Pergulatan Dunia Pesantren: Membangun dari Bawah (Jakarta: P3M, 1985). Persepsi Masyarakat Tentang Kebudayaan (Jakarta: Gramedia, 1985). Konsepsi Manusia dalam al-Qur'an (Jakarta: Pustaka Grafiti, 1985). Intelektual Intelegensia dan Perilaku Politik Bangsa; Risalah Cendekiawan Muslim (Bandung: Mizan, 1992). Perspektif Deklarasi Makkah; Menuju Ekonomi Islam (Bandung: Mizan, 1993), Masyarakat Madani, Kelas Menengah dan Perubahan Sosial (Jakarta: LP3ES dan LSAF, 1996). Ensiklopedia Al-Quran: Tafsir Sosial Berdasarkan Konsep-Konsep Kunci (Jakarta: Paramadina, 1996). Islam dan Transformasi Sosial Budaya (Jakarta: LP3ES, 2000). Paradigma al-Qur'an: Metodologi Tafsir dan Kritik Sosial (Jakarta: PSAP, 2005). ${ }^{20}$

17 Dawam Rahardjo, Ensiklopedi Al-Quran: Tafsir Sosial Berdasarkan Konsep-Konsep Kunci (Jakarta: Paramadina, 2002), xxi.

${ }^{18}$ Dawam Rahardjo, Paradigma Al-Qur'an: Metodologi Tafsir Dan Kritik Sosial (Jakarta: PSAP, 2005), 11.

${ }^{19}$ Raharjdo, Islam Dan Transformasi Sosial-Ekonomi, xi.

${ }^{20}$ Raharjdo, xii. 


\section{Al-Fātiḥah as a Paradigm of Al-Qur'an Interpretation}

To start an interpretation of the Qur'an, it will be tied with the method or concept that will be used in interpreting itself. However, the concept or method used certainly starts from a solid foundation that forms the concept. The basis for forming the concept can be said to be a paradigm. Thomas S. Kuhn said paradigm is a "mode of thought" model or a person's mindset that is used to see something. ${ }^{21}$ In the context of interpretation, a paradigm is a commentator's point of view to see the Qur'an and its interpretation, by positioning "certain ideas" as the starting point and foundation. For example, the concept of Nizam al-Qur'an offered by al-Farahi, departs from the starting point of the taufiqi of the composition of the Qur'an and I'jaz al-Qur'an ${ }^{22}$ or the concept of Wahdatu al-Qur'aniyah promoted by Sa'id Hawa started from the division of the surahs of the Qur'an into four groups and munasabah. ${ }^{23}$ Then, the taufiqi of the composition of the Qur'an and I'jaz al-Qur'an for al-Farahi and the division of the surahs of the Qur'an into four groups for Sa'id Hawa, is the paradigm used to interpreting the Qur'an.

The above description also applies to the interpretation model offered by Dawam Rahardjo, its name the concept of al-Fâtihah as a paradigm of interpretation of the Qur'an. In this regard, there are at least some basic foundations used;

First, it refers to the name that used. For Dawam, al-Fātihah is the Qur'an in nutshell. The word "nutshell' comes from English, consisting of nut which means nuts or seeds, and shell which means; unexploded shells, shells, housings, or grenades. ${ }^{24}$ In other words, the "nutshell" is understood as the wrapping of the nut's contents. So that al-Fātihah is like a peanut shell which has the consequence that the contents of alFâtihah include or wrap up the entire contents of the Qur'an or in other words the essence of the Qur'an is al-Fātihah. Calling al-Fātihah as the Qur'an in nutshell is due to its nature and function as the parent of the Qur'an (ummu al-kitab/ummu al-Qur'an), its essence, and the great Qur'an (al-Qur'an al-Azim). ${ }^{25}$

Al-Fātihah referred to as ummu al-kitab can refer to the term itself in the Qur'an which is mentioned three times, namely Q.S. Ali Imran (03): 07, QS al-Ra'd (13): 39 and al-Zuhruf (43): $04{ }^{26}$ and two of these verses are understood as the 'azaliy knowledge of Allah, ${ }^{27}$ the knowledge of Allah which includes all things, ${ }^{28}$ or Lauh al-

\footnotetext{
${ }^{21}$ Wathani, "Konfigurasi Nalar Tafsir Al-Maqāṣidī Pendekatan Sistem Interpretasi."

${ }^{22}$ Jannah, "Nizāām Al-Qur'ān."

${ }^{23}$ Idris, "Karekteristik Kitab Al-Asas Fi Al-Tafsir Karya Sa'id Hawa."

${ }^{24}$ Victoria Neufeldt dan David B. Guralnik, Webster's New World Dictionary (New York: Prentice Hall, 1991), 932.

${ }^{25}$ Rahardjo, Ensiklopedi Al-Quran: Tafsir Sosial Berdasarkan Konsep-Konsep Kunci, 23-24.

${ }^{26}$ Muhammad Bassām Rusydi, Al-Mu'jam Al-Mufahras Li Ma'ān Al-Qur'an Al- 'Aḍ̂̀m (Bairut: Dar al-Fikr, 1995), 146.

27 Safri Andy, "Hakekat Tafsir Surat Al-Fatihah (Pemahaman Hakikat Ibadah Kepada Allah Swt Dalam Menghadapi Persoalan Kehidupan)," Jurnal At-Tibyan: Jurnal Ilmu Alquran Dan Tafsir 4, no. 1 (2019): 78-100, https://doi.org/10.32505/tibyan.v4i1.827.
} 
Mahfud. ${ }^{29}$ The three verses that mention the term ummu al-kitab, Q.S Ali Imran (03): 07, became the initial foundation by Dawam Rahardjo to position al-Fātihah as a paradigm of al-Qur'an interpretation. Moreover, according to the hadis narrated by Abu Hurairah, the term ummu al-Kitab refers to al-Fātihah, in addition to the terms ummu al-Qur'an, sab'u al-Masani, and al-Qur'an al-Azim. ${ }^{30}$

The attribution of al-Fātihah as ummu al-kitab, of course, is relevant to most commentators who understand al-Fātihah to cover the global content of the Qur'an as a whole. Muhammad Abduh for example, he detailed the contents of al-Fātihah, first: the issue of monotheism refers to the second and fifth verses, second: promises and threats in the first, fourth, and sixth verses, third: about worship in the fifth verse, fourth: laws and regulations in the sixth verse, fifth: historical stories of the past in the last verse. ${ }^{31}$ Regardless of the contents of the letter al-Fātihah, choosing the term ummu al-kitab as the name of the nature of the letter al-Fâtihah is not arbitrary. For example, in the book Sunan at-Tirmizi it is stated that al-Fâtihah is referred to as ummu al-Qur'an, ummu al-kitab and sab'u al-masāni. ${ }^{32}$ Imam al-Qurtubi mentions 12 names of Surah al-Fātihah, namely as-salat, al-hamdu, fatihat al-kitab, ummu al-kitab, ummu al-Qur'an, al-masani, al-Qur'an al-azim, asy-syifa', ar-ruqyah, al-asas, alwafiyah, al-kafiyah. ${ }^{33}$ Not much different, with al-Razi who mentions 12 names, but there are several different terms, namely fatihat al-kitab, al-hamdu, ummu al-Qur'an, sab'u al-Masāni, al-wafiyah, al- kafiyah, al-asas, asy-syifa', as-salat, al-sual, al-syukur, al-du'a. ${ }^{34}$ Apart from the variety and number of names of surah al-Fātihah, not all names of surah al-Fātihah have valid sources, as Bey Arifin argues, such as al-asas, alkanz, asy-syifa and al-du'a. ${ }^{35}$

Second, it still refers to Q.S Ali Imran (03): 07, which mentions the ummu alkitab as muhkamāt verses. Consequently, if the ummu al-kitab in the verse is understood as al-Fātiḥah, it indirectly positions al-Fātiḥah as a muhkamāt verse. On the other hand, verses or surah other than al-Fātiḥah are positioned as mutasyābihāt. Departing from this, methodically al-Fātihah becomes a paradigm, a magnifying glass, or a principle for viewing and highlighting other verses as the body of the al-Qur'an which is mutasyābihāt. ${ }^{36}$

28 Wendi Parwanto, "Struktur Epistemologi Naskah Tafsir Surat Al-Fatihah Karya Muhammad Basiuni Imran Sambas, Kalimantan Barat," Jurnal At-Tibyan: Jurnal Ilmu Alquran Dan Tafsir 4, no. 1 (2019): 143-63, https://doi.org/10.32505/tibyan.v4i1.783.

${ }^{29}$ Quraish Shihab, Tafsir Al-Misbah; Peran, Kesan Dan Keserasian Al-Qur'an (Jakarta: Lentera Hati, 2002), Juz 6, 293.

${ }^{30}$ Ahmad Gunawan, Iyus Supriadi, and Muhamad Wisnu, "Menyingkap Rahasia Surat Al-Fatihah," Madinatul Qur'an: Jurnal Ilmu Al-Qur'an Dan Tafsir 1, no. 1 (2020): 87-98.

31 Ari Susandi, "Nilai-Nilai Pendidikan Islam Dalam Surat an-Nisa ' Ayat 36," Risalah: Jurnal Pendidikan Dan Studi Islam 7, no. 2 (2009): 172-83.

${ }^{32}$ Al-Tirmizi, Al-Jami Al-Kabir (Baghdad: Dar al-Gharbi al-Islami, 1996). Juz 5, 5, No hadis 2875.

${ }^{33}$ Abu Bakar Al-Qurtubi, Al-Jami' Liahkam Al-Qur'an (Bairut: Al-Risalah, 2006). 172-175.

${ }^{34}$ Fahruddin Al-Razi, Mafãtịh Al-Ghaib (Bairut: Dar Ihya al-Turas al-'Arabi, 2000). 179-183.

${ }^{35}$ Gunawan, Supriadi, and Wisnu, "Menyingkap Rahasia Surat Al-Fatihah."

${ }^{36}$ Rahardjo, Ensiklopedi Al-Quran: Tafsir Sosial Berdasarkan Konsep-Konsep Kunci, 24. 
In the history of the discourse of the ulum al-Qur'an, there are many opinions about muhkam mutasyābih, so as-Suyuti recorded more than 10 opinions of scholars. ${ }^{37}$ Opinions about muhkam mutasyābih can be simplified into three categories; namely content theory, practice theory, and understanding theory. The first category understands muhkam and mutasyabih referring to certain verses or surah in the Qur'an. The opinions of Ibn Abbas, ${ }^{38}$ Syamsu Rizal Pangabean ${ }^{39}$ and Muhammad Syahrur ${ }^{40}$ can be included in this category. The theory of practice presupposes whether or not a verse is enforced, so that muhkam are verses that are not written down and mutasyäbih are verses that are texted. ${ }^{41}$ Unlike the previous theories, if the two previous theories talk about the form of understanding about muhkam and mutasyabih, then this theory speaks at the level of "understanding" itself. The basic question in this theory is whether mutasyābih can be understood and explored or not? There are at least three opinions that developed in this regard, namely the opinion of the salaf group (almufawwidah), the khalaf group (al-muawwilah) and the moderate opinion (almutawasitin). ${ }^{42}$

For Dawam Rahardjo himself, muhkam are verses; First, it can be understood directly or has a clear and unequivocal meaning. Second, its meaning can be explained

${ }^{37}$ Al-Suyuti, Al-Itqān Fi 'Uhüm Al-Qur'an, 1335-1338.

${ }^{38}$ The muhkam verse is the ten commandments of Allah swt which are written in Q.S. al-An'am (6): 151-153 which are the ten commandments given to the prophet Moses, while the other verses are mutasyabihat verses. Another opinion attributed to Ibn Abbas that mutasyabihat are verses that are vague to the Jews, namely the surah muqatta'ah. If the 10 commandments are understood as universal laws for humans, then the position of mutasyabih becomes particular law, in the sense that particular law is related to the religious law (ritual) of each individual. Moreover, when it is associated with religious pluralism, the 10 commandments become a benchmark as universal law and become a meeting point for divine religions. Al-Suyuti, 1337.

39 Mutasyabihat are seven stories contained in the QS. al-Syu'ara (26): 10-191, namely the story of the prophet Moses and his followers (verses 10-68), Prophet Ibrahim and his people (verses 69-104), Prophet Noah and his people (verses 105-122), Prophet Hud and his people (verses 123-140), Prophet Salih and his people (verses 141-159) Prophet Lut and his people (verses 160-175), and Prophet Shu'aib and his people (verses 176-191). While muhkam other than the seven stories. Syamsul Rizal Panggabean, “Makna Muhkam Mutasyabih Dalam Al-Qur'an,” Jurnal Ulumul Qur'an 2, no. 7 (1990), 59.

40 Muhkam are verses that are also known as Umm al-Kitab is a collection of laws that were conveyed to the prophet Muhammad, which contains the principles of human behavior such as worship, muamalah, morals that show the apostleship (Minutes) of the Prophet Muhammad. The mutasyabih are divided into two; Al-Qur'an al-Adim and Sab'u al-Masani are a collection of all the essences that Allah gave to the prophet Muhammad, most of which are supernatural, namely things that were not known by human consciousness when the al-Kitab was revealed, such as the verses of the Qur'an. Aqidah verse that shows the prophecy of the prophet Muhammad. Muhammad Shahrur, Prinsip Dan Dasar Hermeneutika Al-Qur'an Kontemporer. Terj. Sahiron Syamsuddin (Yogyakarta: elSAQ Press, 2007), 71-75.

${ }^{41}$ Al-Suyuti, Al-Itqān Fi 'Ulūm Al-Qur'an, 1338.

${ }^{42}$ The opinion of the Salaf group (al-mufawwidah) says that the meanings of mutasyabih traits or verses are left to Allah alone. They cleanse God from this outward understanding that is impossible for God. The khalaf group (Muawwilah), is allowed to interpret rationally with the appropriate understanding and as close as possible to the pronunciation or nat ure of the mutasyabihat verses whose birth meaning is impossible for Allah. While the moderate group (al-mutawasitin) argues that if ta'wil is close to Arabic then it is undeniable, but if ta'wil is far from Arabic then we are tawaqquf. Az-Zarqāni, Manāhil Al-'Irfān Fi 'Ulūm Al-Qur'Ān (Bairut: Dar al-Kitāb al-Arabi, 1995), Juz 2, 226-228. 
by other verses in the Qur'an (mutasyābihāt). Third, it contains a deep meaning. While mutasyābihāt is understood as; first, its meaning is unclear or difficult to understand. Second, being able to explain the verses that are considered muhkamat. Third, its meaning must be confronted with the muhkamat verses so that it is in line and in harmony with them. ${ }^{43}$ The definition offered by Dawam, referring to the first point of the definition of muhkam and mutasyäbihät still dwells in the area of meaning and pronunciation that is firm or ambiguous and can definitively be categorized in the theory of understanding. However, for the next two points of each definition, it deserves to be studied further, because there are no scholars who hold such an opinion. In addition, if Dawam's opinion can be accepted, then it must reconstruct the established knowledge of the Qur'an, because the explanations expressed by Dawam will overlap with the terms mujmal, mubayyan, mutlaq, muqayyad or 'am and khas.

Meanwhile, from an applicative point of view, Dawam's opinion can be classified in content theory and this is the novelty of Dawam's thought which places al-Fâtiḥah as muhkam because it is called ummu al-kitab as in Q.S Ali Imran (03): 07. Dawam's opinion regarding this matter simply matches the existing term ummu al-kitab. In other words, because muhkam is called ummu al-kitab in Q.S Ali Imran (03): 07 and at the same time al-Fātihah is also called ummu al-kitab, it is concluded that al-Fātihah is muhkam. Of course this cannot be taken for granted, for two reasons; First, not all scholars agree that al-Fātihah is called ummu al-kitab, some even reject it such as the opinion of Anas, al-Hasan and Ibn Sirin. ${ }^{44}$ Second, there are no commentators who understand the ummu al-kitab in the context of the verse of Q.S Ali Imran (03): 07 as al-Fātihah. At-Tabari understands the ummu al-kitab in the verse as faraid, hudud, and legal verses. ${ }^{45}$ Ibn Kasir understands the ummu al-kitab as the basis or core of the book because all muhkam verses are written in the entire book, ${ }^{46}$ as well as Ibn 'Asyur in his book, Tahrir wa Tanwir. ${ }^{47}$

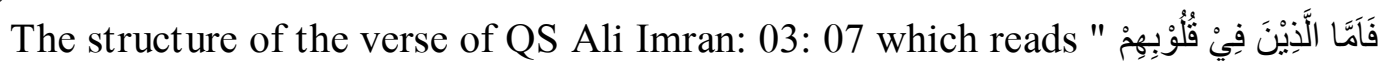

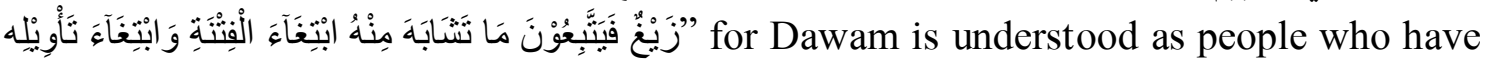
a rotten heart, who follow parts that are vague or unclear, because they aim to to mislead and give their own interpretation. ${ }^{48}$ Therefore, in accordance with the concept he offers, to avoid the two things above, the interpretation of the mutasyā bihā $t$ verses must be returned and contrasted with the sound of al-Fātihah which is muhkam and makes al-Fātihah as a perspective for interpreting verses and surah in Qur'an.

Regarding this muhkam or mutasyabih, Dawam seems inconsistent. In one place, Dawam said that al-Fătihah is a muhkam but when its positions as a perspective in interpreting the Qur'an. However, in other places, he includes surah other than al-

\footnotetext{
${ }^{43}$ Rahardjo, Paradigma Al-Qur'an: Metodologi Tafsir Dan Kritik Sosial, 62-63.

${ }^{44}$ Al-Qurtubi, Al-Jami' Liahkam Al-Qur'an. 172.

${ }^{45}$ Ibn Jarīr Al-Ṭabari, Al-Jāmi' Al-Bayān 'an Ta'Wîl Ay Al-Qur'ān (t.p: Hijr, n.d.). Juz 5, 201.

${ }^{46}$ Ibn Kasir, Tafsir Al-Qur'an Al-'Azim (Bairut: Dar al-Kutub al-Mishri, 2000). Juz 3, 8.

${ }^{47}$ Tahir Ibn 'Asyur, Al-Tahrir Wa Al-Tanwir (Tunisia: al-Dar al-Tunisiyah, 1984). Juz 3, 154.

${ }^{48}$ Rahardjo, Ensiklopedi Al-Quran: Tafsir Sosial Berdasarkan Konsep-Konsep Kunci, 25.
} 
Fātiḥah which are "solid in meaning" such as al-Ikhlas, al-Kafirun or Al-Asr as muhkam as well. ${ }^{49}$ Possibly, this understanding can be called a categorization of muhkam that Dawam offers, but it is not clearly stated. The reading in this context, refers to QS. Hud (11): 1 which explains in its entirety the verses of the Qur'an are muhkamat. While al-Fātihah's muhkam specifically refers to the QS. Ali Imran (03): 07. However, the question that arises from this assumption is understanding the QS. Zumar (39): 23 which implies that the whole verse of the Qur'an is also mutasyabih. ${ }^{50}$ This is a criticism of the immaturity of the foundation of the concept of al-Fâtihah as the Qur'an "in a nutshell” on the one hand and the concept of muhkam or mutasyabih on the other. Alternatively, the standard for determining muhkam or mutasyabih refers to a verse or surah that is "full of meaning" and the existence of an authority -hadithwhich confirms the primacy of the surah. In a hadith, Surah al-Ikhlas is valued with one-third of the Qur'an and al-Kafirun with one-fourth of the Qur'an. For Dawam, the assessment of a third or a quarter of the Qur'an does not mean the value of the reward for reading, but the contents of the surah are explained in one third and one quarter of the Qur'an. ${ }^{51}$ This possibility is more relevant, although it still leaves questions, such as the standard of "meaning dense" in verses and surahs, or what about surah that are dense in meaning but there is no hadith that supports it as in Surah al-Asr.

Third, look at the term al-sab'u al-mas̄āni which is written in QS. al-Hijr (15): 87 and the hadith narrated by Abu Hurairah about the name of the surah al-Fătihah. The term al-sab'u al-maśāni is understood literally, namely seven that are repeated. Al$s a b^{\prime} u$ represents the number of verses of al-Fātihah, while al-maśāni which literally means "two by two" is one that is read twice every rak'ah of prayer. ${ }^{52}$ The interpretation of al-sab'u al-maśāni as al-Fātiḥah is not new and has almost become an agreement by commentators, such as at-Tabari or al-Razi, in addition to being interpreted by the initial seven surah of the mushaf tartibi, namely al-Baqarah, Ali Imran, an-Nisa, al-Maidah, al-An'am, al-A'raf, al-Anfal and at-Taubah. ${ }^{53}$ For the second meaning, it has a weakness that the term al-sab'u al-masiani is part of the letter al-Hijr which came down earlier than the seven letters. So chronologically, it is difficult to represent a verse or letter that has not been revealed. For this reason also, al-Razi rejects and criticizes that al-sab'u al-mas̄anni are the seven letters above. ${ }^{54}$ This is a strong argument for Dawam to conclude that al-sab'u al-maśāni is a surah alFātihah. On the other hand, very few scholars or figures who understand al-sab'u almaśāni not referring to the letter al-Fātihah, for example the opinion of al-Dahak and As-Sya'bi, they both say al-maśāni refers to on a repeated story. ${ }^{55}$ By developing the

\footnotetext{
${ }^{49}$ Rahardjo, 31.

50 Az-Zarkasyì, Al-Burhān Fì 'Ulūm Al-Qur'an, ed. Abu al-Fadl Ibrahim (Kairo: Maktabah Dār alTuras, n.d.), Juz 2, 68.

${ }^{51}$ Rahardjo, Ensiklopedi Al-Quran: Tafsir Sosial Berdasarkan Konsep-Konsep Kunci, 31.

${ }^{52}$ Fahruddin Al-Razi, Mafătị̆ Al-Ghaib (Bairut: Dar Ihya al-Turas al-‘Arabi, 2000), Juz 19, 211.

${ }^{53}$ Al-Razi, Juz 19, 213.

${ }^{54}$ Al-Razi. Juz 19, 213.

${ }^{55}$ Al-Ṭabari, Al-Jāmi' Al-Bayān 'an Ta'Wîl Ay Al-Qur'ān. Juz 14, 121.
} 
opinion of al-Dahak and As-Sya'bi, then Syamsu Rizal Pangabean said al-sab'u almaśāni are seven stories contained in the QS. al-Syu'ara, and for him, al-Fātihah came down after the revelation of the letter al-Hijr, so that al-sab'u al-maśāni does not mean surah al-Fātihah, other than there is no agreement that the number of verses of the letter al-Fātihah is seven. ${ }^{56}$

Based on the text above, Dawam put forward five arguments that underline alFātihaha as a paradigm of interpretation of the Qur'an, namely; ${ }^{57}$

First, the seven verses in al-Fātihah are explained repeatedly throughout the contents of the Qur'an. As Dawam understands about surah al-Ikhlas and al-Kafirun which are worth a third and a quarter, al-Fātiḥah which is called "al-masāani" is not only repeated when praying, but it is understood that the explanation of the surah alFātihah is repeated in the whole Qur'an. ${ }^{58}$ The understanding of "al-masāni" as an explanation that is repeated is a new thing that departs from the argument that, first, the word "al-masāni" linguistically means repeatedly. Second, the content of the letter al-Fātihah itself which includes the main themes or the global content of the contents of the Qur'an, as stated by Abduh's opinion earlier. However, using the narrative "the seven verses in al-Fātiḥah are explained over and over again" is less precise or less specific. Because basically what is repeated is a subsection or a specific explanation of the content of the major themes expressed in Surah al-Fātihah, not the global content of the seven verses of Surah al-Fătihah. Therefore, the question that arises from this, why is al-Fâtihah re-explained in the entire Qur'an? the answer is the next argument.

Second, because the Qur'an is actually the essence of which is included in alFătihah or vice versa. Third, the contents of the Qur'an entirely explain the seven verses in al-Fātihah. This argument departs from Q.S Ali Imran (03): 07 which for Dawam, al-Fātihah functions and is ummu al-kitab and muhkam. Assuming a "comprehensive idea" that needs to be explained simply, al-Fātihah's position is a reflection of a simple explanation of the whole idea. In addition, these two arguments briefly describe the procedure in the concept of al-Fātihah as a paradigm of interpretation of the Qur'an, namely from al-Fātiḥah leading to the entire Qur'an and from the entire Qur'an back to surah al-Fātihahah.

Fourth, the seven verses in al-Fâtihah divide the content of the Qur'an completely. Because al-Fātihah is the core, key or simple explanation of a big and complete idea, other verses will run out to explain al-Fātiḥah. One term in surah alFâtihah contains a broad meaning and needs to be explained with other verses in the Qur'an. Based on all the previous arguments, the conclusions are; Fifth, al-Fātihah is called the great Qur'an, because al-Fātiḥah is the Qur'an "in a nutshell”. Al-Fātihah is a paradigm for interpreting the Qur'an.

\footnotetext{
${ }^{56}$ Panggabean, "Makna Muhkam Mutasyabih Dalam Al-Qur'an.”, 49.

${ }^{57}$ Rahardjo, Ensiklopedi Al-Quran: Tafsir Sosial Berdasarkan Konsep-Konsep Kunci, 23.

${ }^{58}$ Rahardjo, 31.
} 


\section{Procedure for Tafsir al-Qur'an with Al-Fātiḥah Paradigm}

In the tradition of interpreting the Qur'an, recognizing the terms method, style, source, or approach that seems to overlap between one opinion and another. ${ }^{59}$ In this case, in order not to be confused in understanding the meaning of the procedure, we borrow the mapping or categorization carried out by Islah Gusmian. The term procedure in this context is the stages or steps that must be taken in the evolutionist interpretation of the al-Fātihah paradigm, in Islah Gusmian language it can be matched with the systematic presentation of the interpretation which is divided into two, coherent and thematic. ${ }^{60}$

The procedure that Dawam offers in the interpretation of the Qur'an based on alFâtiḥah is like an inductive and deductive pattern which then in its systematic embodiment is thematic. In accordance with his thinking which states that the systematic presentation of the musalsal method or the interpretation of verse by verse or tartīb mushafi, is irrelevant to the current context. ${ }^{61}$ Furthermore, according to him, thematic interpretation can take three forms; departing from social science concepts such as the word democracy, from key terms in the Qur'an such as the word iman, taqwa or ihsan, and terms or concepts in Islamic scientific traditions such as shari'ah or tauhid. $^{62}$

The interpretation procedure with the concept of al-Fātihah as a nutshell, first, starts from the surah al-Fātihah and spreads throughout the verses of the Qur'an. In this stage, register and enter key terms one by one in Surah al-Fātiḥah, such as rabb, hamdalah, dīn, rahmān or rahīm. Then the interpretation of the keyword is searched for in the body - mutasyabihat verses - the Qur'an. ${ }^{63}$ In the process, a historical approach tartīb nuzūl- and paying attention to other key terms, be they synonyms or antonyms, is needed to derive new meaning structures and evolutionist dimensions. For example, looking for the meaning of the term as-sirat or rabb, you will find the terms sabil, tahriq, Allah, or Ilah. ${ }^{64}$

The evolutionist referred to by Dawam can be understood as the gradual development of the meaning or explanation of the key terms sought, in accordance with the same terms found in the verses of the Qur'an in tartīb nuzīl. For example, the word $r a b b$ will explain that, Allah as the most gracious creator, is one form of Allah's most merciful nature in the form of teaching people what they do not know (al-Alaq [96]: 1,3). Only to Allah we worship sincerely, because only to Him we worship and make him as a protector, as the Lord of the east and the West and the giver of the way to get to him (al-Muzammil [73]: $8,9,19$ ) and so on. ${ }^{65}$

\footnotetext{
${ }^{59}$ Gusmian, Khazanah Tafsir Indonesia: Dari Hermeneutika Hingga Ideologi, 116.

${ }^{60}$ Gusmian, 122.

${ }^{61}$ Rahardjo, Ensiklopedi Al-Quran: Tafsir Sosial Berdasarkan Konsep-Konsep Kunci, 33.

${ }^{62}$ Rahardjo, 6-7.

${ }^{63}$ Rahardjo, 30.

${ }^{64}$ Rahardjo, 23.

${ }^{65}$ Rahardjo, 21.
} 
The steps of interpretation offered by Dawam are not complete from the first stage to the end. However, for the first procedure, in terms of substance, it is no different from the systematic procedure for presenting thematic interpretations in general. In this case, quoting al-Farmawy's opinion, the thematic interpretation procedure, namely; determine the problem or theme to be discussed, collect verses related to the problem, compile a series of verses according to the time of their revelation, understand the munasabah of these verses, complete the discussion with relevant hadiths, finally study the verses as a whole from all aspects. ${ }^{66}$ The absence of a gradual step of interpretation is understandable considering that al-Fātihah as the Qur'an in a nutshell is positioned as a paradigm of interpretation of the Qur'an which will result in an evolutionist interpretation. However, as stated by Dawam, thematic interpretation is relevant for today and can start from three patterns, one of which is from key terms in the Qur'an. Therefore, al-Fātihah as a paradigm of interpretation of the Qur'an, will depart from key terms or meanings in the Qur'an, either from Surah alFātiḥah or others.

The second way is to see the entire contents of the Qur'an from the perspective of al-Fātihah. Unlike the first method, in this second method, we interpret several verses, a group of verses or surah and then confront them with the muhkam verses, namely al-Fātihah as the paradigm. In this way, deviations from the interpretation of the main idea-according to al-Fātihah-as far as possible will be avoided. ${ }^{67}$ For example QS. Al-Lahab (111) describes a person who hinders and challenges the truth, namely the messenger of Allah. The above description does not only apply to Abu Lahab or his wife, in the present context anyone can be classified as Abu Lahab if they have the same characteristics. This surah, when confronted with al-Fātiḥah as an interpretive paradigm, is included in the "maghdub" group or those who are affected by Allah's wrath because of attitudes and actions that are against the truth. ${ }^{68}$

This second method, in its form, will remain thematic, because after interpreting a certain verse we enter and match the essence of the interpretation with the key terms or sub-sections of it in Surah al-Fātihah. In short, this second procedure is the opposite of the first procedure. The obstacle that may be faced is matching the interpreted verse with the terms in Surah al-Fātiḥah and of course it looks subjective, especially when you look at the generality of the terms or content in Surah al-Fātihah. For example in QS. Al-Maun (107) narrates the behavior and attitudes of people who lie to religion, for Dawam they are all included in the "maghdub" group. The question is, why are they not included in the lost "dallin" group? Based on the 4 and 5 verses, it mentions people who have prayed, even though they are negligent. ${ }^{69}$ Likewise, the 6 verse describes

${ }^{66}$ Al-Farmawi, Al Bidāyah Fì Al-Tafs̄̄r Al-Maudū' I (Kairo: Matba'ah al-Hadarah al ᄀ-Arabiyah, 1977)., 114.

${ }^{67}$ Rahardjo, Ensiklopedi Al-Quran: Tafsir Sosial Berdasarkan Konsep-Konsep Kunci, 28.

${ }^{68}$ Rahardjo, 26.

${ }^{69}$ In the 4 verse, scholars differ on the mukhatab in that verse. One opinion says the hypocrites, another opinion says the believers. These differences will affect the meaning of "sāhū $n$ " in the 5 verse, 
people who do good but because of riya, not because of Allah. The nature of neglect or riya is closer to being classified as "dhallin" who are lost, because they have done good, but are wrong. ${ }^{70}$ Another example on QS. al-Qadr (97), this surah describes the revelation of the Qur'an on the night of lailatul qadr, a night better than 1000 months, where the angels are sent down and full of prosperity. If you want to contradict this surah with al-Fātihah, it will be difficult to determine it directly. However, there are several possibilities, first, it can be included in the term "rahim" if it puts forward the meaning of a peaceful night that God has given as a form of love. Second, entering the "sirat al-mustaqim" refers to the revelation of the Qur'an as rules and instructions to reach the straight path. ${ }^{71}$ Third, on the term "rabb al-alamin" because Allah, Lord of the worlds, is able to regulate the virtue of one night compared to 1000 months and the angels descend with his permission.

\section{Implementation of interpretation}

As previously explained, there are two procedures in the concept of al-Fātihah as a paradigm of interpretation of the Qur'an. The first example, take the keyword "نَسنتَعِيْنُ" "نستعون" then wawu was replaced with ya' which came from the word "عان - -عون". In the Qur'an, the word with its various derivations is mentioned 9 times, namely in QS. Al-Furqan (25): 4, QS. Al-Kahf (18): 95, QS. alMaidah (5): 2, QS. al-Fātiḥah (1): 5, QS. al-Baqarah (2): 45 and 153, QS. al-A'raf (7): 128, QS. Yusuf (12): 18, and QS. Al-Anbiya (21): $112 .^{72}$

All these verses can be divided into two major themes, human's relationship with God and human's relationship with his fellow human beings. For the last theme written in QS. Al-Furqan (25): 4, which describes the attitude of the Meccan disbelievers not to believe in the Qur'an as a revelation and miracle from Allah, for the prophet Muhammad. They thought that the Qur'an was Muhammad's creation and was assisted by people who had converted to Islam. ${ }^{73}$ Then on QS. Al-Kahfi (18): 95, in the form of the story of Dzulqarnain who refused a reward or payment at the request of making a wall. However, instead of rewards and payments, Dzulqarnain asked for help to cooperate with each other in building the wall. ${ }^{74}$ Lastly on QS. al-Maidah (5): 2, contains orders to believers to help each other in terms of goodness and piety, and do not help each other in sin and enmity. In the context of this verse, “ وَتَعَاوَنُوا عَلَى الَِِِِْ

namely; first; "sāh $\bar{u} n "$ means leaving the prayer, second, ending the prayer, third, when the prayer does not remember Allah. Al-Razi, Mafätih Al-Ghaib, Juz 32, 334.

70 Another example that is in line with the grouping of "maghdub" or "dhallin" is the term "ashabu al-masyamah /syimal" in the QS. Al-Waqiah (56), whether to be included in the "maghdub" or "dallin" group.

${ }^{71}$ As the general opinion of the commentators who say that "sirat al-mustaqim" is the book of Allah (al-Qur'an) or the religion of Islam. Ibn Jarīr Al-Ṭabari, Al-Jāmi' Al-Bayān 'an Ta'Wìl Ay Al-Qur'ān (t.p: Hijr, n.d.), 173.

${ }^{72}$ Muhammad Fu'ad 'Abd Al-Bāqī, Al-Mu'jam Al-Mufahras Li Al-Fād Al-Qur'an Al-Karìm (Kairo: Dar al-Hadis, n.d.), 494.

${ }^{73}$ Al-Marāghī, Tafsir Al-Marā ghī, Juz 18, 151.

${ }^{74}$ Al-Marāghī, Juz 16, 18. 


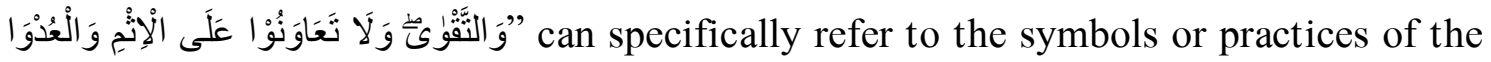
pilgrimage, waging war in the month that is forbidden, and disturbing animals or people who will do business and perform Hajj in Mecca. ${ }^{75}$

The second theme relates to the relationship of a servant with Allah, referring to QS. al-Fātiḥah (1): 5, QS. al-Baqarah (2): 45 and 153, QS. al-A'raf (7): 128, QS. Yusuf (12): 18, and QS. Al-Anbiya (21): 112.

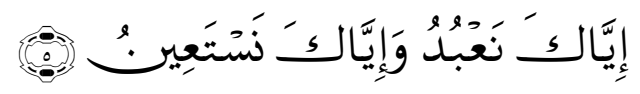

Translation: You (Alone) we worship, and You (Alone) we ask for help (for each and everything) (QS. al-Fātiḥah [1]: 5).

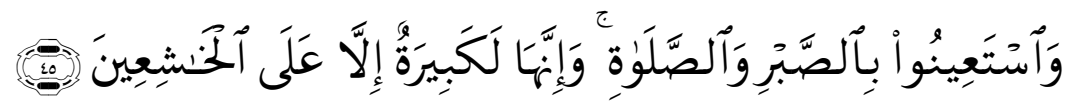

Translation: And seek help through patience and prayer; and indeed, it is difficult except for the humbly submissive [to Allāh]. (QS. al-Baqarah [2]: 45).

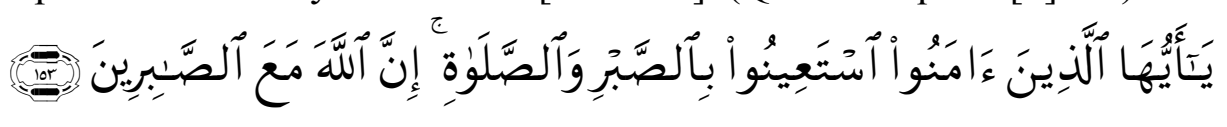

Translation: O you who have believed, seek help through patience and prayer. Indeed, Allāh is with the patient. (QS. al-Baqarah [2]: 153).

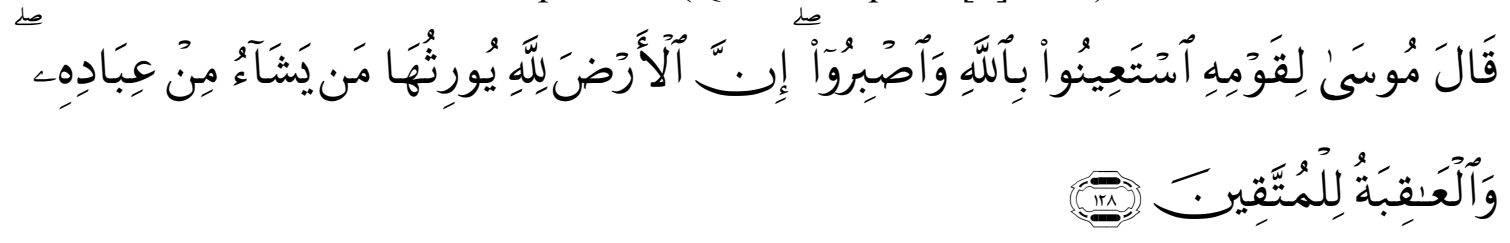

Translation: Said Moses to his people, "Seek help through Allāh and be patient. Indeed, the earth belongs to Allāh. He causes to inherit it whom He wills of His servants. And the [best] outcome is for the righteous." (QS. alA'raf [7]: 128).

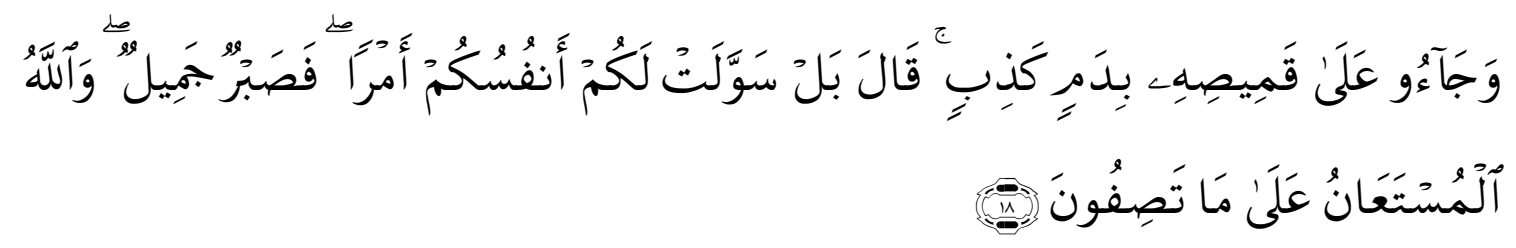

Translation: And they brought upon his shirt false blood.[588] [Jacob] said, "Rather, your souls have enticed you to something, so patience is most fitting. And Allāh is the one sought for help against that which you describe." (QS. Yusuf [12]: 18).

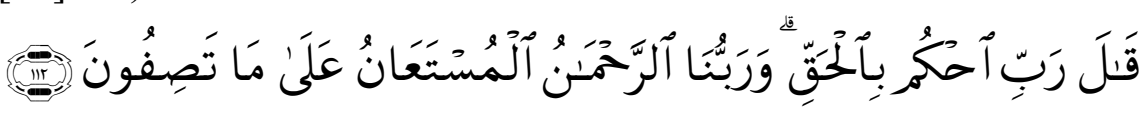

Translation: [The Prophet] has said, "My Lord, judge [between us] in truth. And our Lord is the Most Merciful, the one whose help is sought against that which you describe." (QS. Al-Anbiya [21]: 112).

\footnotetext{
${ }^{75}$ Al-Marāghī, Juz 6, 45.
} 
On QS. al-Fâtihah (1): 5 is the essence and essence of tauhid, that only to Allah we worship and only to him we ask for help. Of course this verse does not contradict the QS. al-Maidah (5): 2, because in essence we only ask God for help, but through the intermediary of fellow humans. ${ }^{76}$ While in Yusuf (12): 18, Allah is said to be "الْمُسنتَعَانُ" Essence and a place to ask for help. Likewise in Al-Anbiya (21): 112, which is "الرَّحْنُنُ" which means that the form of his affection is to grant what is asked for and fulfill the help desired by his servant. In addition, the word structure in this pronunciation is in the form of the jumlah ismiyah - noun sentences - which have the meaning of tsubut (fixed). In contrast to the structure in QS. al-Fātihah (1): 5 in the form of the jumlah fi'liyah -verbal sentences-, which have repeated and continuous meanings. ${ }^{77}$ This difference shows that Allah is the only one and remains the place to ask for help and in asking for help not only once, but must be repeated and continuous.

While at QS. al-Baqarah (2): 45 and 153, QS. al-A'raf (7): 128 shows how we can get help, namely by being patient and praying. Both of these things are in line with the sentence structure in QS. al-Fātihah (1): 5, the sentence " إِيَّالكَ نَعْبُدُ" takes precedence over "وَاِيَّاكَ نَسْنََِيْنِن ". Therefore, before asking God for help, worship is preceded, because help is the fruit or result of worship. ${ }^{78}$ Patience in the context of this verse is understood as refraining from all things that are hated, including being patient in carrying out worship and staying away from all things that are prohibited. ${ }^{79}$ Another understanding, patiently waiting for help and the request itself. While prayer as a medium of $i$ 'anah is confirmed by the hadith narrated by Abu Hudaifah, that when the Prophet was facing a problem or problem, he immediately performed the prayer. ${ }^{80}$

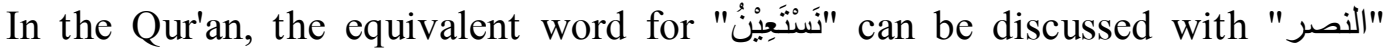
which in all its derivations is mentioned up to 143 times and the word "الدعاء "wich is

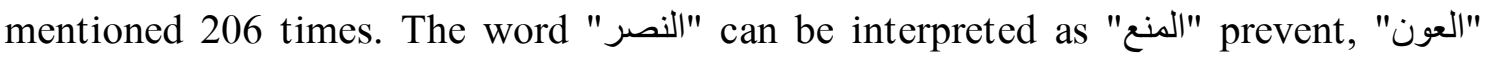
help, "الظفر" victory and "revenge. For the meaning of help as in QS. Al-Hasyr (59): 10 or QS. Al-Hajj (22): 40. ${ }^{81}$ While the word "الدعاء" has several meanings, namely the word "قولا", "عبادة", the call "نداء", help "الاستعانة", the question "خذل" is which is mentioned 3 times in the Qur'an, namely QS. Ali Imran (3): 160, QS. Al-Furqan (25): 29 and al-Isra '(17): 22, all of which are interpreted by leaving or not helping. ${ }^{83}$ Observing at a glance, the difference between "النصون "and the last word is identical or always related to a quarrel, dispute or enmity, so we need help. While

${ }^{76}$ Abduh, Tafsir Al-Manār, 58.

${ }^{77}$ Khālid Usmān Al-Sabt, Qawā'id Al-Tafs̄ir Jam'an Wa Dirasah (Madinah: Dar Ibn 'Affān, n.d.), 259.

${ }^{78}$ Abduh, Tafsir Al-Manār, 61.

79 Al-Alūsī, Rūhh Al-Ma'ānī Fì Tafsìr Al-Qur'an Al-'Aḍ̄m Wa Sab'u Al-Màisānì (Bairut: Iḥyā alTurās al-'Arabī, n.d.), 248.

${ }^{80}$ Al-Alūsī, 249.

${ }^{81}$ Harun Bin Musa, Al-Wujūh Wa Naḍāir Fi Al-Qur'an Al-Kārim (Baghdad: Dar al-Saqafah, 1988), 250.

${ }^{82}$ Musa, 313.

${ }^{83}$ Al-Bāqī, Al-Mu’jam Al-Mufahras Li Al-Fād Al-Qur'an Al-Kan̄m, 227. 
"النصر "العون", which is a help that does not have to be preceded by a dispute or hostility. Likewise with "العون" with "الدعاء", the last term generally applies to the existence of inequality between the requester and the giver of help, while the first term, does not have to be equal when asking for help. Thus, the pronunciation

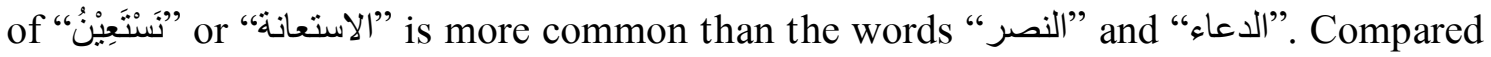
to the word "النصر" denotes all kinds of help, not just based on conflict. Meanwhile, compared to "الدعاء" الاستعانة", the word shows the closeness between the requester and the giver of help.

The second example is QS. an-Nisa (4): 171 which talks about "ghuluw" in religion. The same thing is also found in QS. al-Maidah (5): 77, the two verses are as follows;

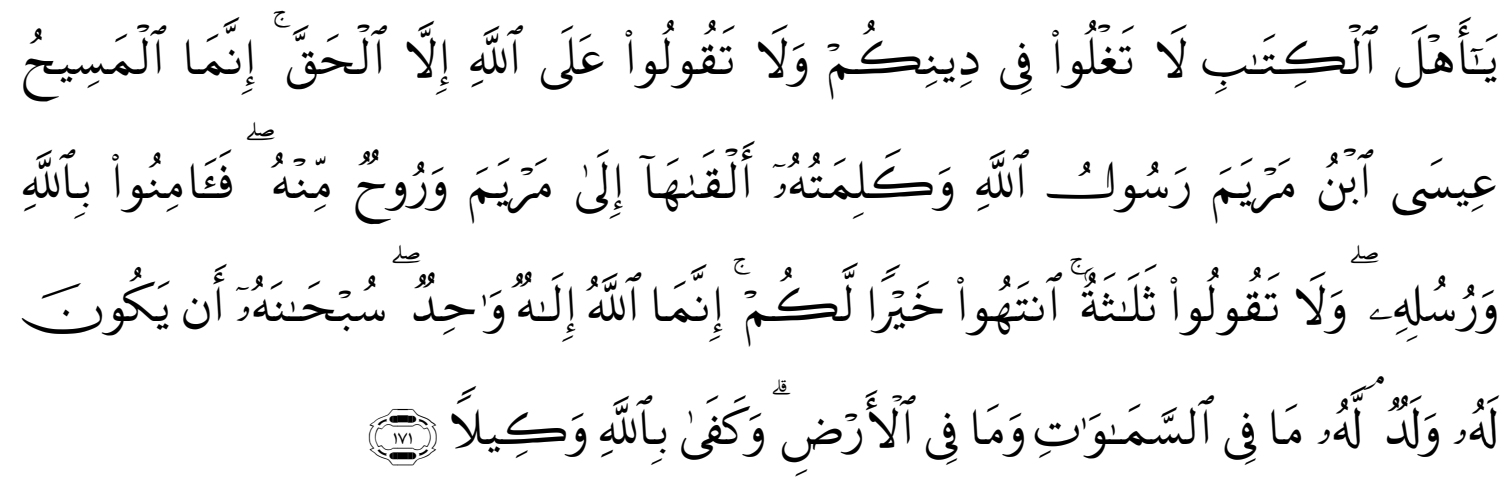

Translation: O People of the Scripture, do not commit excess in your religion or say about Allāh except the truth. The Messiah, Jesus the son of Mary, was but a messenger of Allāh and His word which He directed to Mary and a soul [created at a command] from Him. So believe in Allāh and His messengers. And do not say, "Three"; desist - it is better for you. Indeed, Allāh is but one God. Exalted is He above having a son. To Him belongs whatever is in the heavens and whatever is on the earth. And sufficient is Allāh as Disposer of affairs. (QS. an-Nisa [4]: 171).

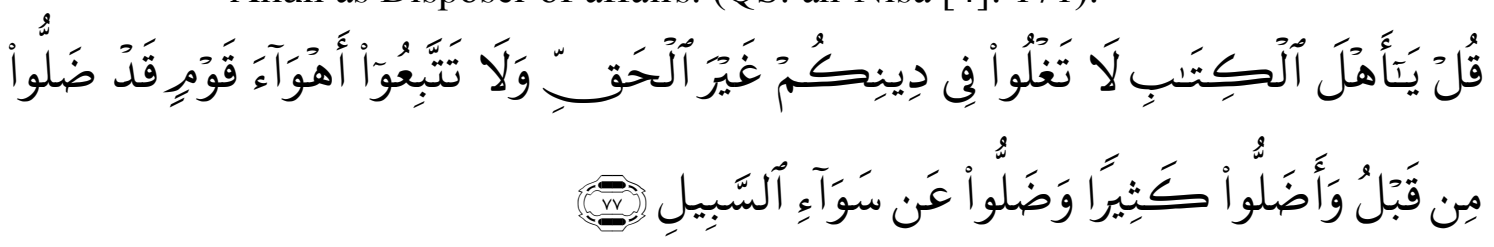

Translation: Say, "O People of the Scripture, do not exceed limits in your religion beyond the truth and do not follow the inclinations of a people who had gone astray before and misled many and have strayed from the soundness of the way." (QS. al-Maidah [5]: 77).

The two verses above refer to the people of the book as their mukhatab, but the first verse more explicitly refers to the people of Prophet Jesus or Christians. Historically, these two verses were revealed in the Medina period, where the Muslim community has interacted directly with other divine religions, namely Christianity and Judaism. This underlies that these two verses criticize the religious ways of Christians and Jews who are considered to be "guluw" excessively in religion. 
The word "guluw" comes from the word galä-yaghiu-guluwwan which means zā da (increase), irtaf'a (up), Jawaz had or naqī ruhsi (denies lightening). Thus, "guluw" can simply be understood as an excessive act or behavior towards something that has set limits or standards. ${ }^{84}$ For Raghib al-Asfihani, "guluw" can be in the form of exceeding the limit in position, measure or size. ${ }^{85}$ Therefore, in the context of the verse above, "guluw fi al-din", is an exaggeration in religion, be it an understanding or worship. In a hadith tells how three companions of the Prophet wanted to worship more than the worship of the Prophet Muhammad. The first friend said "I will do the night prayers continuously", the second friend said "I will fast all my life and not break the fast" and the last one said "I will stay away from women, so I will not marry forever". Then the Prophet replied, "I am the most fearful and pious of Allah among all of you, but I fast and break my fast, pray and sleep, and marry women. ${ }^{86}$ The hadith explains that the Prophet forbade his followers to be excessive in worship or carrying out religious orders.

Referring to QS. al-Maidah (5): 77, it is implied that guluw in religion is possible to be divided into two, namely haq (true/commendable) and bātil (wrong/despicable). Exaggeration rightly and commendably can take the form of exaggeration in giving praise to good deeds. Meanwhile, for guluw in a bad or despicable religion, as in QS. an-Nisa (4): 171, can be; first, saying that Prophet Isa was the son of Allah or Allah himself. Second, God is three. In addition, as the guluw in the religion of the Jews, among others; excessively criticizing Prophet Isa or Prophet Muhammad and excessive in glorifying their apostles. ${ }^{87}$ This attitude is considered as "ḍalh 'an sawāi al-sabì " lost in the straight path, namely an attitude that is middle, moderate and balanced. This middle attitude becomes the character of Islam, in QS. al-Baqarah (2): 143 it is stated that Muslims are made as "wasatan" people, people who are middle and moderate, not extreme right or left, not excessive in religion such as Christians or Jews. ${ }^{88}$

Guluw in religion is certainly not limited to the cases above and as a warning and prohibition for Christians or Jews only, but also for Moslems. Thus, in the current context, if there is a Moslem who is excessive in religion, it is too exalting for someone and is considered ma'sum, for example. This indicates that the person has fallen into religion. Therefore, the two verses above which talk about guluw, when confronted with al-Fātihah as the paradigm of interpretation of the Qur'an, are further information from the 7 verse of the surah al-Fātihah. More specifically, it describes the lost “dallin” group.

\footnotetext{
${ }^{84}$ Ibn Manzhur, Lisan Al-Arabi (Bairut: Dar al-ma'arif, n.d.), Juz 36, 3292.

${ }^{85}$ Ar-Raghib Al-Ashfahani, Mufradat Alfaz Al-Qur'an (Damaskus: Dar al-Qalam, 2009), 613.

${ }^{86}$ Muhammad bin Isma'il Al-Bukhari, Sahih Al-Bukhari (Bairut: Dar Ibn al-Kasir, 2002), Bab alTargib fi al-Nikah, No. 5063, 1292.

87 , Asyur, Juz 6, 51.

${ }^{88}$ Al-Ṭabari, Al-Jāmi' Al-Bayān 'an Ta’Wīl Ay Al-Qur'ān, Juz 2, 626.
} 


\section{Conclusion}

The concept of interpretation of al-Fātihah as a paradigm of interpretation of the Quran offered by Dawam, is based on two verses of the Quran, namely QS. Ali Imran (03): 07 and QS. al-Hijr (15): 87. From these two verses emerge three main frameworks, namely al-Fātiḥah as ummu al-kitab, al-Fātiḥah as muhkam verse and another verse categorized as mutasyabihat, lastly al-Fātiḥah as al-sab'u al-maśāni. These three frameworks, although generally understood to be almost the same as Dawam, in some respects there are differences and this can be said to be a gap from the concept of al-Fātihah as a paradigm of interpretation of the Qur'an.

The first framework, for example, scholars agree that another name for Surah alFâtihah is ummu al-kitab, but in the context of the verse of QS Ali Imran (03): 07, the term ummu al-kitab is al-Fâtihah, none of the scholars argue like that. This is the novelty of Dawam's thinking. Second, because of its position as ummu al-kitab, consequently al-Fātiḥah is a muhkam verse and positions other than al-Fātihah as mutasyabihat. In this context, Dawam does not have a clear standard in determining the surah or verse that is muhkam or mutasyabihat, because for him, the QS. al-Ikhlas or QS. al-Asr as muhkam anyway. While the last framework, regarding al-sab'u almaśāni, until now, there is no unanimous agreement about the meaning and purpose of al-sab'u al-mas̄āni.

In the applicative realm, this interpretation concept is manifested in the systematics of writing thematic interpretations with two procedures, namely starting from al-Fātihah then spreading to all verses of the Qur'an and from verses, groups of verses or surah in the Qur'an and then returning to al-Fātihah. In the example, "نَسنَتِيْنِن in Surah al-Fātiḥah shows generality compared to the words "الدعاء" and". Asking for help with the editor of "نَسْنَِِْنِنِ is not only related to the existence of hostility, quarrels, or disputes, but help in everything. Likewise, asking for help with the editorial "نَسنَعَِيْنُ instead of the pronunciation "الدعاء", shows the closeness between the requester and the giver of help. As for the second procedure, take the example of two verses that have the same theme, namely QS. an-Nisa (4): 171 and QS. al-Maidah (5): 77. Both of them talk about the attitude of someone who is low in religion. The guluw attitude in the two verses above, when viewed from the perspective of alFātihah, is included in the "dallin" group who went astray. 


\section{REFERENCES}

Achmad. "Manhaj Abd. Muin Salim Dan Penerapannya Dalam Menafsirkan Surah AlFatihah." Al-Daulah 1, no. 1 (2012): 16-32.

Al-Alūsī. Rūh Al-Ma'ān̄ Fì Tafš̀r Al-Qur'an Al- 'Aḍ̂̀m Wa Sab'u Al-Masān̄̄. Bairut: Ihyā al-Turās al-'Arabī, n.d.

Al-Ashfahani, Ar-Raghib. Mufradat Alfaz Al-Qur'an. Damaskus: Dar al-Qalam, 2009.

Al-Bāqī, Muhammad Fu'ad 'Abd. Al-Mu'jam Al-Mufahras Li Al-Fāẹ Al-Qur'an AlKañm. Kairo: Dar al-Hadis, n.d.

Al-Bukhari, Muhammad bin Isma'il. Sahih Al-Bukhari. Bairut: Dar Ibn al-Kasir, 2002.

Al-Qurtubi, Abu Bakar. Al-Jami’ Liahkam Al-Qur'an. Bairut: Al-Risalah, 2006.

Al-Razi, Fahruddin. Mafâtih Al-Ghaib. Bairut: Dar Ihya al-Turas al-'Arabi, 2000.

Al-Sabt, Khālid Usmān. Qawā'id Al-Tafs̄ì Jam’an Wa Dirasah. Madinah: Dar Ibn 'Affān, n.d.

Al-Suyuti. Al-Itqān Fi 'Uhūm Al-Qur'An. Saudi: Mamlakah al-'Arabiyya alSu'udiyyah, n.d.

Al-Ṭabari, Ibn Jarīr. Al-Jāmi' Al-Bayān 'an Ta'Wìl Ay Al-Qur'ān. t.p: Hijr, n.d.

Andy, Safri. "HAKEKAT TAFSIR SURAT AL-FATIHAH (Pemahaman Hakikat Ibadah Kepada Allah Swt Dalam Menghadapi Persoalan Kehidupan)." Jurnal AtTibyan: Jurnal Ilmu Alquran Dan Tafsir 4, no. 1 (2019): 78-100. https://doi.org/10.32505/tibyan.v4i1.827.

Az-Zarkasyì. Al-Burhān Fì 'Ulüm Al-Qur'An. Edited by Abu al-Fadl Ibrahim. Kairo: Maktabah Dār al-Turas, n.d.

Az-Zarqāni. Manāhil Al-'Irfăn Fi 'Uhūm Al-Qur'Ān. Bairut: Dar al-Kitāb al-Arabi, 1995.

Chodjim, Ahmad. Alfatihah: Membuka Mata Batin Dengan Surat Pembuka. Jakarta: Serambi, 2008.

Dozan, Wely, and Konsentrasi Studi Qur' An Hadits. "Analysis Of Shifting Interpretation Paradigm: A Comparative Study Of Classic And Contemporary Era Tafsirs." At-Tibyan: Jurnal Ilmu Alqur'an Dan Tafsir 5, no. 1 (2020): 37-55. https://doi.org/10.32505/tibyan.

Gunawan, Ahmad, Iyus Supriadi, and Muhamad Wisnu. "Menyingkap Rahasia Surat Al-Fatihah.” Madinatul Qur'an: Jurnal Ilmu Al-Qur'an Dan Tafsir 1, no. 1 (2020): 87-98.

Guralnik, Victoria Neufeldt dan David B. Webster's New World Dictionary. New York: Prentice Hall, 1991.

Gusmian, Islah. Khazanah Tafsir Indonesia Dari Hermeneutika Hingga Ideologi. Yogyakarta: LKIS Pelangi Aksara, 2013.

Harahap, Rindom. “Tafsir Bil Ma’tsur Jalaluddin Rakhmat.” El-Afkar 5, no. II (2016): 61.

Idris, Mhd. "Karekteristik Kitab Al-Asas Fi Al-Tafsir Karya Sa'id Hawa." Ulunnuha 8, no. 1 (2019): 115-26.

Jannah, Miftahul. 'Niz̄ām Al-Qur'ān.” MAGHZA: Jurnal Ilmu Al-Qur'an Dan Tafsir 3, no. 1 (2018): 79-92. https://doi.org/10.24090/maghza.v3i1.1957.

Kasir, Ibn. Tafsir Al-Qur'an Al-'Azim. Bairut: Dar al-Kutub al-Mishri, 2000.

Luqman, Fadhli. "Konsep Kunci Tafsir Alquran Ala Dawam Rahardjo." Jurnal Ilmu Alquran \& Hadis 4, no. 1 (2014). 
Manzhur, Ibn. Lisan Al-Arabi. Bairut: Dar al-ma'arif, n.d.

Parwanto, Wendi. "Struktur Epistemologi Naskah Tafsir Surat Al-Fatihah Karya Muhammad Basiuni Imran Sambas, Kalimantan Barat." Jurnal At-Tibyan: Jurnal Ilmu Alquran Dan Tafsir 4, no. 1 (2019): 143-63. https://doi.org/10.32505/ tibyan.v4i1.783.

Rahardjo, Dawam. Ensiklopedi Al-Quran: Tafsir Sosial Berdasarkan Konsep-Konsep Kunci. Jakarta: Paramadina, 2002.

- Paradigma Al-Qur'an: Metodologi Tafsir Dan Kritik Sosial. Jakarta: PSAP, 2005.

Raharjdo, Dawam. Islam Dan Transformasi Sosial-Ekonomi. Jakarta: LASF, 1999.

Rusydi, Muhammad Bassām. Al-Mu'jam Al-Mufahras Li Ma'ān Al-Qur'an Al-'Aḍ̄m. Bairut: Dar al-Fikr, 1995.

Shahrur, Muhammad. Prinsip Dan Dasar Hermeneutika Al-Qur'an Kontemporer. Yogyakarta: elSAQ Press, 2007.

Shihab, Quraish. Tafsir Al-Misbah; Peran, Kesan Dan Keserasian Al-Qur'an. Jakarta: Lentera Hati, 2002.

Subrayogo, Imam. Metodologi Penelitian Sosial-Agama. Bandung: Remaja Rosda Karya, 2001.

Susandi, Ari. "Nilai-Nilai Pendidikan Islam Dalam Surat an-Nisa' Ayat 36." Risalah: Jurnal Pendidikan Dan Studi Islam 7, no. 2 (2009): 172-83.

Umar, Nasarudin. "Refleksi Sosial Dalam Memahami Al-Qur'an: Menimbang Ensiklopedi Al-Qur' an Karya M. Dawam Raharjdo." Jurnal Studi Al-Qur'an 1, no. 3 (2006).

Wathani, Syamsul. "Konfigurasi Nalar Tafsir Al-Maqāṣidī Pendekatan Sistem Interpretasi." Suhuf 9, no. 2 (2016): 293-319.

Zulaiha, Eni. "Tafsir Feminis: Sejarah, Paradigma Dan Standar Validitas Tafsir Feminis." Al-Bayan: Jurnal Studi Ilmu Al- Qur'an Dan Tafsir 1, no. 1 (2016): 1726. https://doi.org/10.15575/al-bayan.v1i1.1671. 